Mateusz ĆwikŁa

Uniwersytet Pedagogiczny, Kraków, Polska

\title{
Przemiany strukturalne w produkcji autobusów w Polsce
}

\section{Structural changes in the production of buses in Poland}

Streszczenie: Polska należy do czołowych producentów autobusów w Europie. W naszym kraju funkcjonują fabryki takich zagranicznych korporacji, jak: MAN, Scania czy Volvo. Rodzimym potentatem pojazdów komunikacji miejskiej jest Solaris Bus \& Coach. Polska staje się europejskim centrum produkcji autobusów miejskich, a zlokalizowane w naszym kraju fabryki należą do najnowocześniejszych w Europie.

W 2013 roku produkcja autobusów w Polsce osiągnęła poziom 3715 pojazdów. Jest to o 4,17\% więcej niż w 2012 roku. Wzrost ten był spowodowany zwiększonym eksportem autobusów oraz rosnącym popytem na krajowym rynku. Zdecydowanym liderem wśród producentów autobusów w Polsce jest MAN Bus, który w 2013 roku wyprodukował 1512 autobusów, czyli o 11,18\% więcej niż w roku poprzednim. Drugie miejsce w Polsce pod względem wielkości produkcji zajął Solaris Bus \& Coach. Bramy polskiej fabryki w Bolechowie opuściło łącznie 1229 autobusów (w porównaniu do 2012 r. więcej o 23,35\%). Trzecie miejsce zajęła firma Volvo Buses, która w 2013 roku wyprodukowała łącznie 699 autobusów, czyli tyle samo co w roku poprzednim. Biorąc pod uwagę rejestrację nowych pojazdów, w 2013 roku zarejestrowano w Polsce 1389 autobusów, czyli o 7,92\% więcej niż w 2012 roku. Po przeanalizowaniu rejestracji nowych autobusów w Polsce należy zaznaczyć, że w 2013 roku autobusowym liderem był Mercedes-Benz (542 pojazdy). Drugie miejsce w rankingu zajął Solaris Bus \& Coach z wynikiem 318 wozów. Na trzecim miejscu, z liczbą 63 autobusów, uplasował się MAN Bus.

\begin{abstract}
Poland is one of the leading bus manufacturers in Europe. In our country there are factories of such foreign-owned corporations as: MAN, Scania, and Volvo. Solaris Bus \& Coach is a locally-owned tycoon in public transport vehicles production. Poland is becoming a manufacturing centre of European city buses and Polish bus factories are one of the most modern factories in Europe.

In 2013 Polish factories assembled 3838 buses, which is $4,17 \%$ more than in 2011 . This is due to the increase in both the export of public transport vehicles and the demand for such goods on the domestic market. MAN Bus, with its bus production of 1512 in 2013, which is $11,18 \%$ more than in 2012 , is the leader among bus manufacturers in Poland. Located in Bolechowo, Solaris Bus \& Coach is the second biggest manufacturer in the country. In 2013, the total of 1229 buses were assembled in their factory, 23,35\% more when compared with 2012 production. Volvo Buses, which produced 699 vehicles in 2013 (the same as in 2012) ranks third. As far as the registration of new vehicles is concerned, it should be noted that in 2013, as many as 1389 buses were registered, which is 7,92\% more when compared with the number of buses registered in 2012 .
\end{abstract}


As for the data concerning the registration of new buses in 2013, the numbers point to the leadership of Mercedes-Benz, which is followed by Solaris Bus \& Coach, and MAN Bus, with 417; 318; and 63 vehicles respectively.

Słowa kluczowe: Autosan; produkcja autobusów; MAN; Mercedes-Benz; Scania; Solaris; Volvo

Keywords: Autosan; assembling of busses; MAN; Mercedes-Benz; Scania; Solaris; Volvo

\section{WsTĘP}

Przemysł motoryzacyjny odgrywa kluczową rolę w gospodarce europejskiej ze względu na swój udział w wielu innych dziedzinach przemysłu, takich jak produkcja części i podzespołów, elektronika, informatyka, telekomunikacja i logistyka. Poprzez zapewnienie wysokich wpływów z handlu zagranicznego, podatków oraz wdrażania najnowszych technologii oddziałuje na umocnienie pozycji Europy i zwiększenie jej konkurencyjności na światowych rynkach. Europejskie Stowarzyszenie Producentów Pojazdów (ACEA, European Automobile Manufacturer's Association) reprezentuje 13 czołowych europejskich producentów samochodów osobowych, samochodów ciężarowych i autobusów. Członkami ACEA są: Grupa BMW, DAF Trucks, DaimlerChrysler, FIAT, Ford of Europe, General Motors Europe, MAN Nutzfahrzeuge, Porsche, PSA Peugeot Citroën, Renault, Scania, Volkswagen i Volvo. Koncerny motoryzacyjne zrzeszone w ACEA produkują w Europie ponad $18 \mathrm{mln}$ pojazdów rocznie, zatrudniają bezpośrednio ponad 1,2 mln osób, pośrednio zaś zapewniają pracę ponad 10 mln ludzi. Wg danych stowarzyszenia ACEA z Belgii w 2012 roku rejestracja nowych autobusów ważących powyżej 3,5 t na europejskim rynku kształtowała się na poziomie 33890 autobusów, o 197 więcej niż rok wcześniej. Polska jest trzecim co do wielkości producentem autobusów w Europie, wyprzedzają nas tylko Szwecja i Niemcy (PZPM, 2013).

Celem niniejszej publikacji jest ukazanie tendencji przemian w zakresie produkcji autobusów w Polsce w ciągu ostatnich kilkunastu lat. Produkcja autobusów, wg Polskiej Klasyfikacji Działalności, posiada kod 29.10.C. Podklasa ta obejmuje produkcję autobusów, trolejbusów i autokarów oraz produkcję podwozi do autobusów. Analiza danych na przestrzeni lat ukazuje zachodzące zmiany w zakresie produkcji autobusów przez konkretne przedsiębiorstwa oraz liczbę zarejestrowanych nowych pojazdów w Polsce. W publikacji dokonano również oceny kondycji ekonomiczno-finansowej rodzimych producentów autobusów.

Zakres przestrzenny pracy obejmuje zasadniczo teren Polski, jednakże do celów porównawczych wykorzystano dane z innych krajów europejskich. Fabryki produkujące autobusy w Polsce zlokalizowane są w następujących województwach: wielkopolskim, pomorskim, dolnośląskim, świętokrzyskim, kujawsko-pomorskim oraz podkarpackim.

Sytuacja branży autobusowej została przeanalizowana w oparciu o metody: statystyczną, analizę porównawczą oraz opisową. Wykorzystano głównie informacje zawarte w Strategii Rozwoju Transportu Ministerstwa Infrastruktury, Diagnozie polskiego transportu oraz Raporcie o stanie handlu zagranicznego wydanym przez Ministerstwo Gospodarki. Istotnym i przydatnym źródłem wiedzy były również artykuły wydawane w ramach Prac 
Komisji Geografii Przemysłu Polskiego Towarzystwa Geograficznego. Analiza produkcji autobusów opierała się w głównej mierze na Banku Danych Lokalnych GUS, danych portalu transportu publicznego Infobus, informacji Polskiego Związku Przemysłu Motoryzacyjnego (PZPM) oraz firmy JMK Analizy Rynku Transportowego.

Zakres czasowy publikacji obejmuje lata 2000-2013, co w dużej mierze wynika z faktu, iż rozwój przemysłu motoryzacyjnego branży autobusowej rozwijał się na terenie Polski od początku XXI w.

KsZTAŁTOWANIE SIĘ RYNKU AUTOBUSÓw W LATACH 2000-2013

Polski rynek przewozów pasażerskich w pierwszej dekadzie XXI wieku cechował systematyczny regres przewozów autobusami i autokarami w ruchu pozamiejskim. W latach 2003-2009 liczba pasażerów przewożonych autobusami i autokarami przez przedsiębiorstwa zatrudniające powyżej 9 osób zmalała z 823 do $613 \mathrm{mln}$ (spadek o 25,5\%). Na te procesy nakładał się gwałtowny wzrost motoryzacji indywidualnej - zwiększyła się liczba samochodów osobowych (wzrost o 45\%), a co za tym idzie, również intensywność ich wykorzystania oraz liczba osób podróżujących autami osobowymi.

W produkcji autobusów dla polskiego rynku strategiczny jest segment autobusów miejskich. W latach 2000-2010 miała miejsce reforma systemu transportu pasażerskiego w miastach. Wprowadzone rozwiązania zmierzały w kierunku dostosowania tego transportu do realiów gospodarki rynkowej. Dotyczyło to zarówno powoływania spółek prawa handlowego, przekształcania zakładów budżetowych w spółki prawa handlowego, jak i oddzielania działalności organizatorskiej od przewozowej. W 2010 roku przewozy miejskie pasażerów realizowało 110 przewoźników, w tym ok. 10\% byli to przewoźnicy prywatni (Diagnoza polskiego transportu, Ministerstwo Infrastruktury).

W latach 2007-2013 samorządy, uzyskawszy dostęp do dużych środków unijnych, znaczną ich część przeznaczyły na rozwój transportu zbiorowego. Według wyliczeń Izby Gospodarczej Komunikacji Miejskiej w latach 2007-2013 wydano z dotacji UE aż 19 mld zł na komunikację miejską. Unijne dofinansowanie wynosiło w tych projektach średnio ok. 61\% tzw. kosztów kwalifikowanych. Znaczną część tych środków wykorzystano na zakup nowoczesnego taboru, głównie autobusów.

Paradoksem jest fakt, że często nowe pojazdy są droższe w eksploatacji od starych. Nowoczesne miejskie autobusy spalają więcej paliwa, bo są wyposażone w klimatyzację, dodatkowe urządzenia i systemy elektroniczne (np. wyświetlacze). Są też znacznie droższe w serwisowaniu (Krzemiński, 2013). Szansą na rozwiązanie tego problemu jest stosowanie w autobusach alternatywnych układów napędowych - hybrydowych, elektrycznych czy zasilanych LPG. Te rozwiązania konstrukcyjne charakteryzują się niższym kosztem eksploatacji i niskim poziomem hałasu, są funkcjonalne i spełniają rygorystyczne normy czystości spalin. Jednocześnie należy pamiętać o takich negatywnych cechach, jak: wysoka cena autobusu 
nowej technologii, drogie komponenty oraz mniejsze osiągi i parametry jezdne (Chłopek $\mathrm{i}$ in., 2011).

Ogólna liczba autobusów i autokarów w Polsce zwiększyła się w latach 2005-2013 z 79,6 tys. do 103 tys. (ryc. 1). Fakt ten należy powiązać z wejściem Polski do Unii Europejskiej i uruchomieniem funduszy na ten cel.

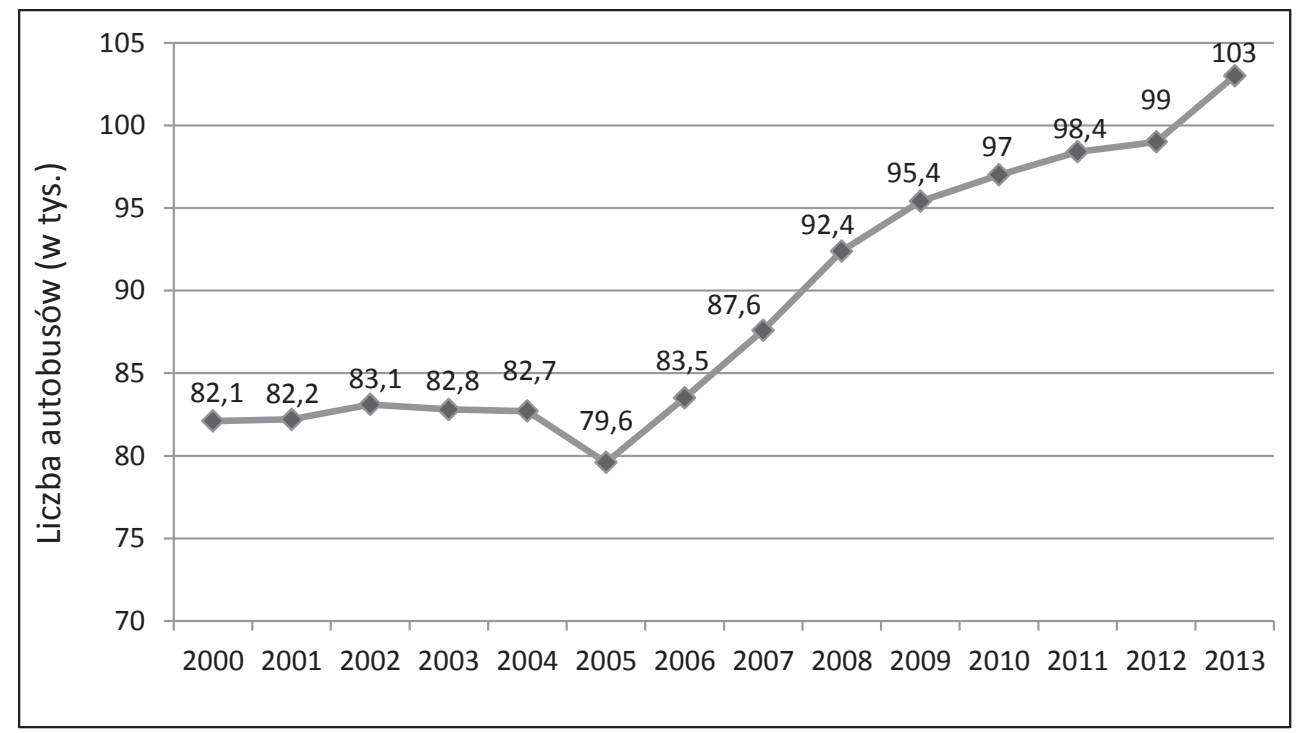

Ryc. 1. Liczba autobusów zarejestrowanych w Polsce w latach 2000-2013

Źródło: opracowanie własne na podstawie Banku Danych Lokalnych GUS

Analiza liczby autobusów miejskich w ostatnich latach wykazuje wzrost taboru (11,23 tys. autobusów w 2004 r. w stosunku do 11,96 tys. w 2012 r. - ryc. 2). W większym stopniu powiększyła się liczba autobusów pozamiejskich (wzrost o 17,4\%). Wzrost ten nie miał jednak uzasadnienia w wielkości zapotrzebowania na autobusowe i autokarowe przewozy pasażerskie, które w tym okresie zmniejszyły się z 30 do 24,4 mld pasażerokilometrów $(-18,7 \%)$ (Diagnoza polskiego transportu, Ministerstwo Infrastruktury).

Pomimo dużych nakładów na komunikację miejską w Polsce dane Izby Gospodarczej Komunikacji Miejskiej pokazują, że jest to bardzo powolny środek transportu. Średnia prędkość jazdy autobusów miejskich w latach 2005-2011 wzrosła z 18,5 do zaledwie 19 km/h, a należy pamiętać, że szybkość przemieszczania się komunikacją miejską to jeden z głównych czynników przesądzających o jej konkurencyjności. W najbliższych latach sytuacja nie poprawi się. Wiele komunalnych przedsiębiorstw komunikacji miejskiej będzie jeszcze długo spłacać kredyty, zaciągnięte w celu zapewnienia wkładu własnego przy unijnych inwestycjach. W dalszym ciągu potrzeby inwestycyjne są ogromne. Mimo dużego unijnego wsparcia w latach 2007-2013 tylko częściowo udało się nadrobić wcześniejsze zaniedbania (Krzemiński, 2013). Ponad połowa miejskich autobusów w 2010 roku miała więcej niż 15 lat (ryc. 3). 


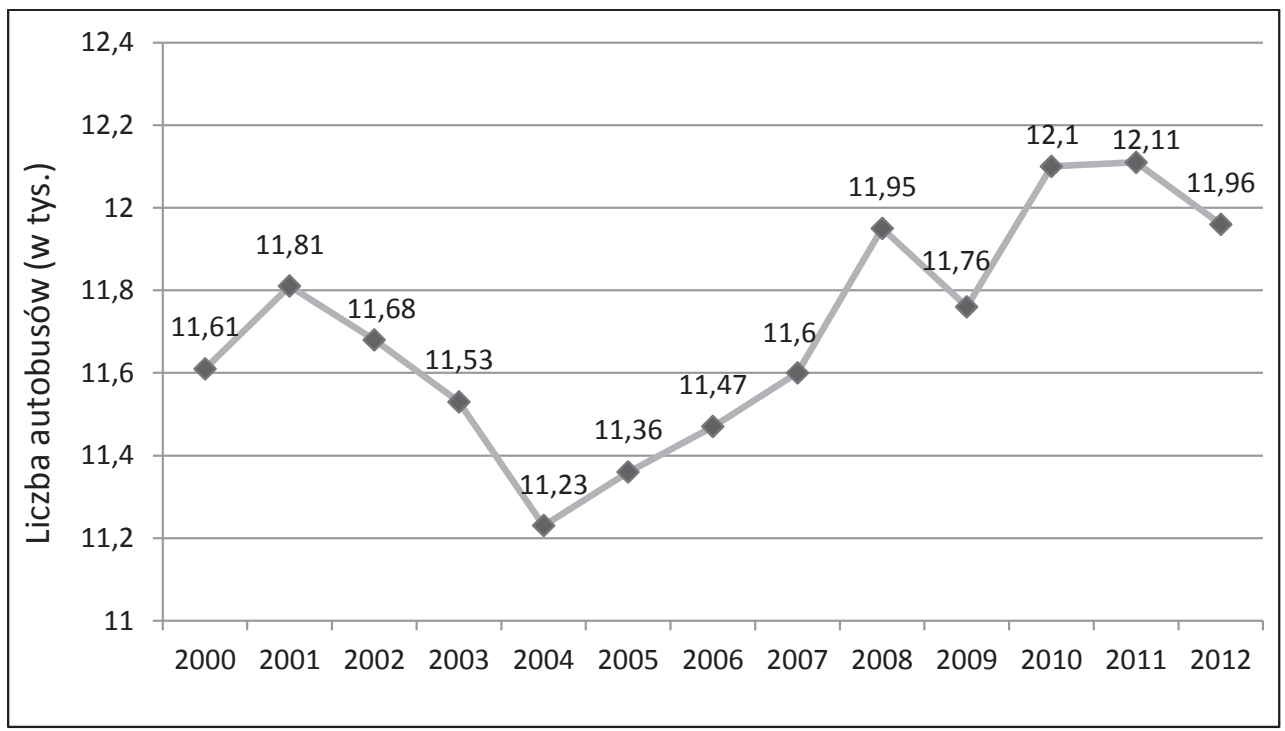

Ryc. 2. Liczba autobusów w komunikacji miejskiej w Polsce w latach 2000-2012

Źródło: opracowanie własne na podstawie Banku Danych Lokalnych GUS

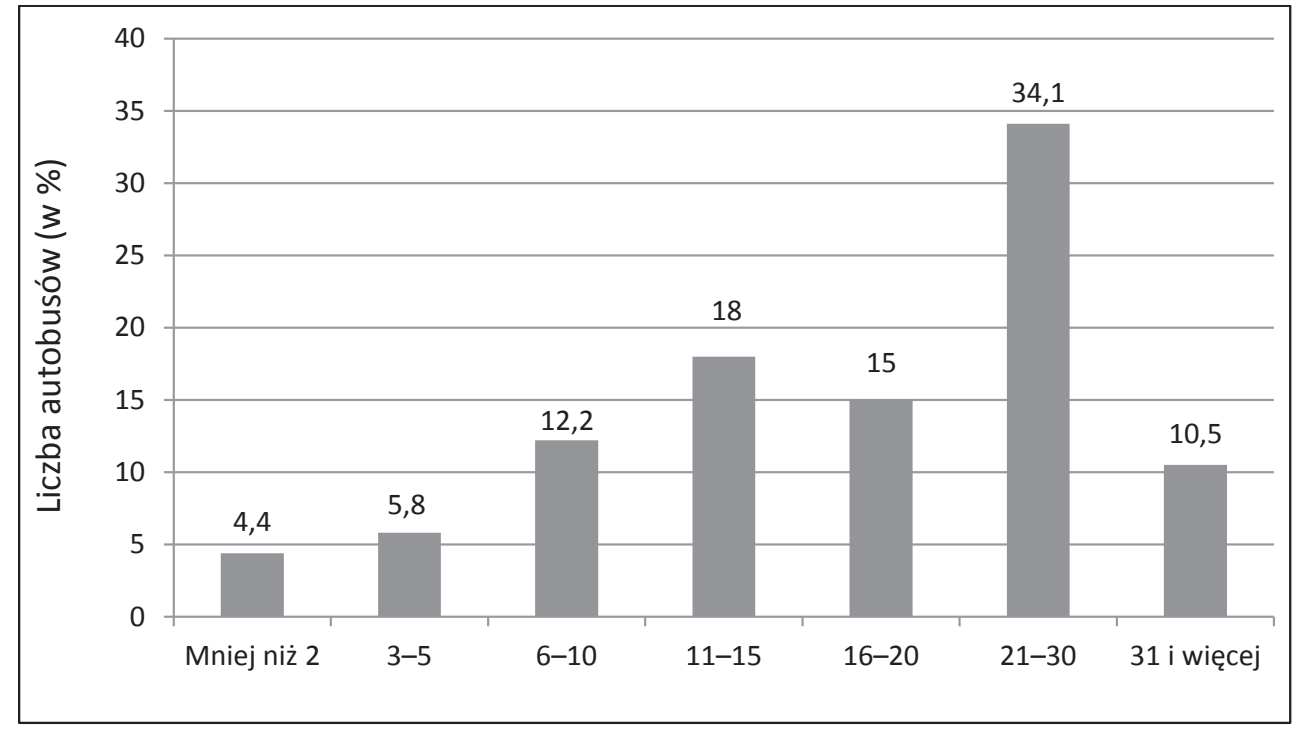

Ryc. 3. Struktura wiekowa autobusów w 2010 roku w Polsce

Źródło: opracowanie własne na podstawie Banku Danych Lokalnych GUS

Średni wiek taboru autobusowego w ostatnich latach został nieco odmłodzony. Wycofywane są najczęściej wysłużone ikarusy, a takie miasta, jak: Warszawa, Wrocław, Poznań, Kraków, Olsztyn, Płock, Toruń, Kielce czy Opole, już zakupiły po kilkanaście 
nowych autobusów. Inne miasta, jak np. Katowice, Rzeszów, Łódź, Bydgoszcz, Siedlce czy Włocławek, planują w najbliższym czasie nowe inwestycje w tym zakresie.

Eksport autobusów w Polsce na przestrzeni ostatnich kilkunastu lat sukcesywnie wzrastał, z zaledwie 370 pojazdów w 2001 roku do 3980 w 2009 roku (ryc. 4). Intensywny wzrost eksportu po 2004 roku to w dużym stopniu tzw. efekt kreacji handlu związany z uczestnictwem w rynku wewnątrzwspólnotowym. Liberalizacja wymiany handlowej została zapoczątkowana w okresie przedakcesyjnym, ostatnie cła na towary przemysłowe zniesiono na dwa lata przed wstąpieniem do UE. Na wzrost eksportu istotny wpływ miały również zwiększony napływ bezpośrednich inwestycji zagranicznych oraz wewnętrzna restrukturyzacja przedsiębiorstw wymuszona koniecznością dostosowania standardów technicznych i technologicznych do wymogów unijnych (Wieloński, 2010).

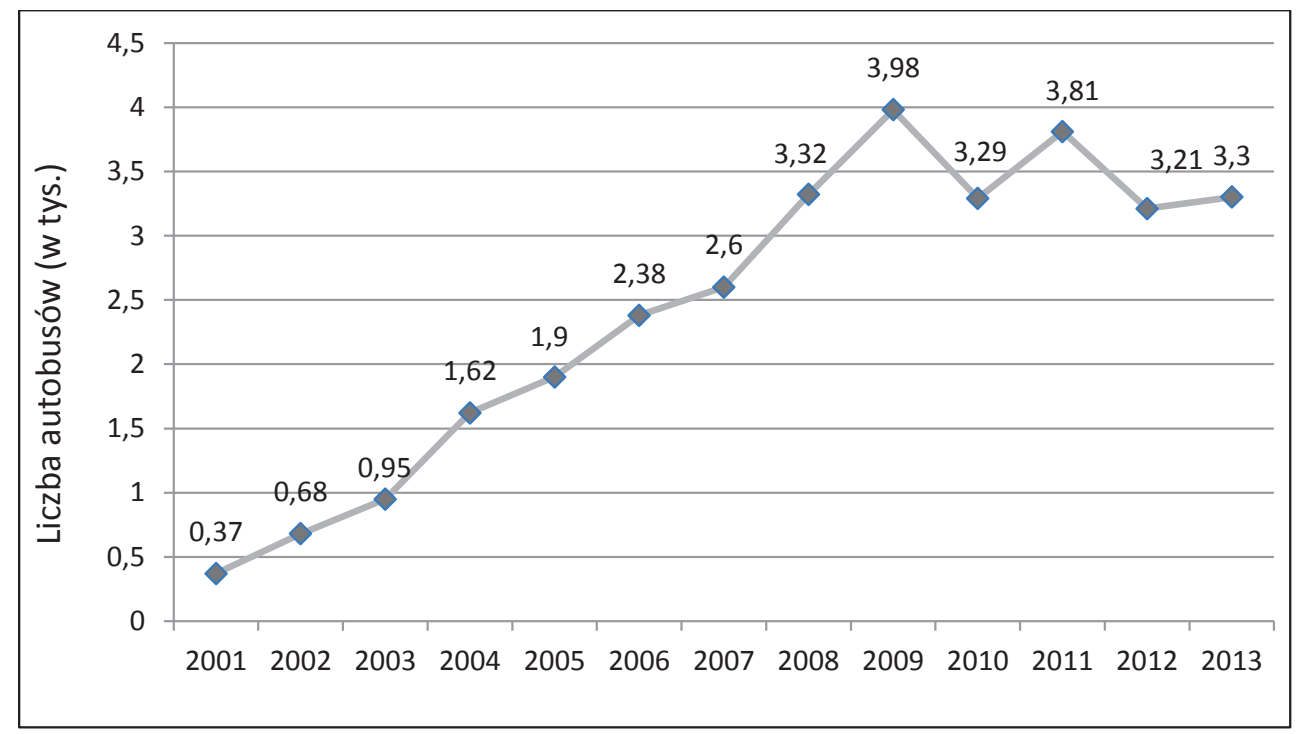

Ryc. 4. Eksport autobusów z Polski w latach 2000-2013

Źródło: opracowanie własne na podstawie JMK Analizy Rynku Transportowego

W 2010 oraz 2012 roku nastąpił spadek eksportu autobusów z Polski do poziomu 3210 sztuk. Decydujący wpływ na to miało pogorszenie koniunktury na głównych rynkach unijnych oraz rynkach Europy Środkowo-Wschodniej. Kryzys finansowy, który dotarł ze Stanów Zjednoczonych do Europy, przyczynił się do zmniejszenia aktywności realnej gospodarki. Pozostałe czynniki, jakie mogły wywrzeć wpływ na wielkość polskiego eksportu w ostatnich latach, to: kryzys zadłużeniowy w strefie euro, wzrost cen surowców na rynkach światowych. Należy pamiętać, że w strukturze polskiego eksportu (według sekcji Międzynarodowej Standardowej Klasyfikacji Handlu) największy udział w 2010 roku miały maszyny, urządzenia i sprzęt transportowy - 42,98\% (Polska 2012. Raport o stanie handlu zagranicznego, 2012). 
Na ryc. 5 krzywa produkcji i eksportu autobusów pokazuje, że prawie całość produkcji polskiego przemysłu motoryzacyjnego w tym obszarze jest kierowana na eksport (w 2013 roku było to aż $88,9 \%$ ).

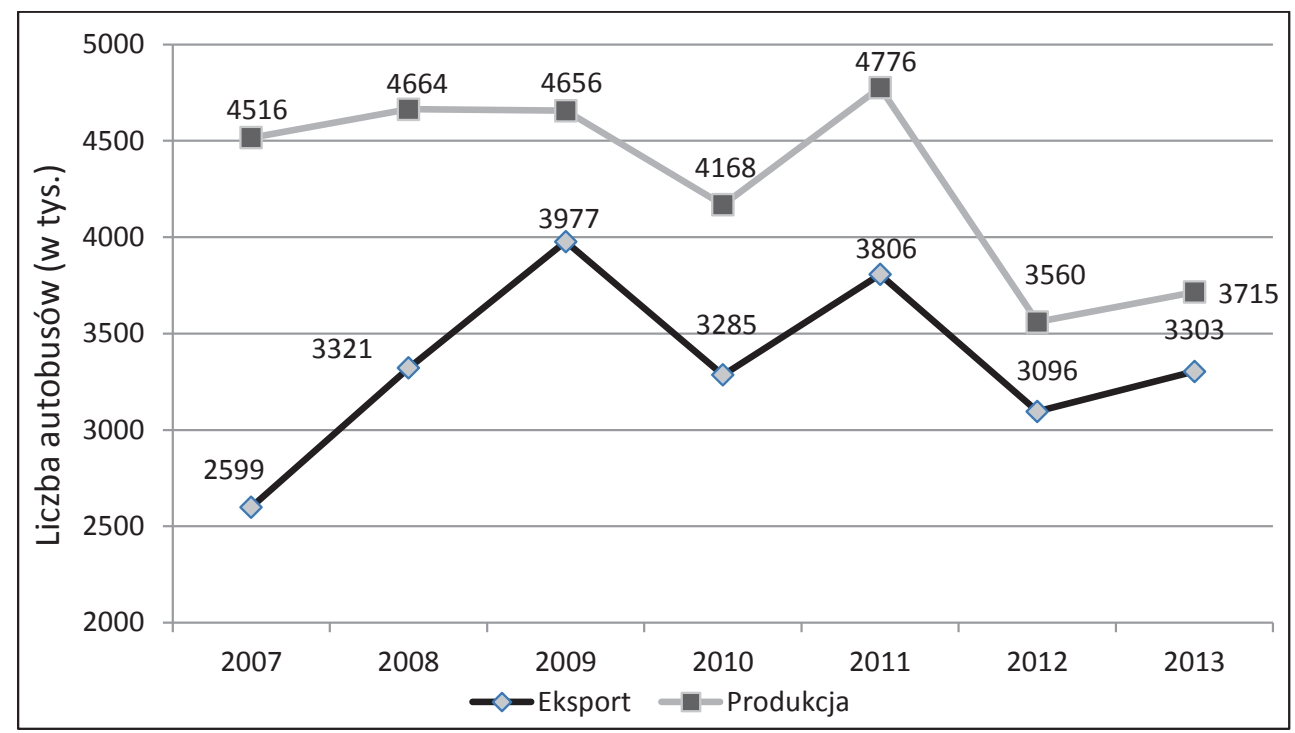

Ryc. 5. Produkcja i eksport autobusów z Polski w latach 2007-2013

Źródło: opracowanie własne na podstawie JMK Analizy Rynku Transportowego 2014

Tab. 1. Najwięksi odbiorcy autobusów wyprodukowanych w Polsce w 2013 roku

\begin{tabular}{|c|l|c|c|}
\hline Lp. & \multicolumn{1}{|c|}{ Kraj } & 2013 & Udział w eksporcie autobusów [\%] \\
\hline 1 & Niemcy & 839 & 22,58 \\
\hline 2 & Szwecja & 530 & 14,27 \\
\hline 3 & Norwegia & 413 & 11,12 \\
\hline 4 & Polska & 412 & 11,09 \\
\hline 5 & Francja & 280 & 7,54 \\
\hline 6 & Serbia & 199 & 5,36 \\
\hline 7 & Szwajcaria & 122 & 3,28 \\
\hline 8 & Izrael & 116 & 3,12 \\
\hline 9 & Bułgaria & 109 & 2,93 \\
\hline 10 & Włochy & 104 & 2,80 \\
\hline 11 & Inne kraje & 591 & 15,91 \\
\hline$\sum$ & Razem & 3715 & 100,00 \\
\hline
\end{tabular}

Źródło: opracowanie własne na podstawie JMK Analizy Rynku Transportowego 2014 
Struktura geograficzna polskiego eksportu autobusów ukierunkowana jest na kraje europejskie. Największymi odbiorcami pojazdów w 2013 roku byli Niemcy, Szwedzi oraz Norwegowie. W tabeli poniżej przedstawiono największych zagranicznych odbiorców autobusów wyprodukowanych w Polsce w 2013 roku.

Na produkcję autobusów mają wpływ kwestie gospodarcze w naszym kraju. Z tego punktu widzenia istotna jest kwestia zatrudnienia. Najwięksi producenci autobusów zatrudniają w Polsce kilka tysięcy osób. W tab. 2 została przedstawiona struktura zatrudnienia pracowników.

Tab. 2. Zatrudnienie pracowników w firmach produkcyjnych w Polsce w 2013 roku

\begin{tabular}{|l|c|}
\hline \multicolumn{1}{|c|}{ Nazwa firmy } & Zatrudnienie (liczba osób) \\
\hline Volvo Buses & 2550 \\
\hline MAN Bus & 2450 \\
\hline Solaris Bus \& Coach & 2300 \\
\hline Scania Production Słupsk & 500 \\
\hline Autosan & 360 \\
\hline Solbus & 250 \\
\hline Kapena & 250 \\
\hline Łącznie & 8660 \\
\hline
\end{tabular}

Źródło: KPMG, JMK Analizy Rynku Transportowego 2014

TRANSFORMACJA GOSPODARKI I JEJ WPEYW NA RODZIMĄ PRODUKCJĘ AUTOBUSÓW

Procesy transformacji gospodarki, w tym sektora przemysłu i usług, należą do ciągle aktualnych problemów badawczych. Wynikają one z ogólnych tendencji rozwoju cywilizacyjnego, które uwidaczniają się w zmianach struktur sektorowo-przestrzennych. Stanowią one wyraz różnych właściwości podmiotów gospodarczych, które mogą charakteryzować się: wzrostem ekonomicznym, stagnacją, recesją, zanikaniem, a także powstawaniem nowych firm (Zioło, 2010). Proces upadłości w czasach kryzysu wiąże się z niepokojącym zjawiskiem problemów finansowych dużych, do niedawna silnych kapitałowo przedsiębiorstw. Spowolnienie polskiej gospodarki w czasach światowego kryzysu gospodarczego spowodowało również postawienie w stan upadłości rodzimych fabryk produkujących autobusy (Bauer, 2010).

Autosan jest jedną z najstarszych fabryk w Polsce, jej początki sięgają 1832 roku. Początkowo w zakładach z Sanoka trudniono się rzemiosłem, następnie aż do 1950 roku wytwarzano w nich wagony i maszyny. Sanocka Fabryka Wagonów Sanowag produkowała nadwozia samochodów osobowych i pojazdów pożarniczych. Przełom nastąpił w 1958 
roku, kiedy to powstał model San H01 - zapoczątkował on nowy etap samodzielnej produkcji autobusów. Zmieniono wówczas też nazwę firmy na Sanocką Fabrykę Autobusów Autosan, która przetrwała aż do transformacji ustrojowej. Autosan w latach 1950-1990 zapewniał duże ilości tanich autobusów na potrzeby krajowe. W szczytowym okresie, pod koniec lat 70., ich produkcja przekraczała 4000 pojazdów rocznie (4220 w 1978 roku). Zatrudnienie w firmie sięgało 7 tys. osób.

W 1994 roku zawarto umowę pomiędzy Autosanem i firmą Sobiesław Zasada Centrum SA o konwersji długów na akcje. Sanocki producent znalazł się tym samym w mocnej grupie autobusowej, gdyż Zasada zmonopolizował rok później produkcję autobusów w Polsce, kupując także Jelcza. W czasach PRL-u tylko te dwie fabryki mogły produkować autobusy (Osenkowski, 1995).

Od 2001 roku firma projektowała i produkowała elementy pojazdów szynowych, zwłaszcza nadwozia szynobusów i tramwajów. Współpracowała głównie z: PESA Bydgoszcz, NEWAG z Nowego Sącza i z Poznańskimi Zakładami Naprawczymi Taboru Kolejowego. Do poprawy sytuacji w Autosanie przyczyniły się po 2003 roku kontrakty na dostawy autobusów do Wielkiej Brytanii, Szwecji, Rumunii, na Słowację i na Węgry.

W 2008 roku ogłoszono upadłość części firmy Jelcz, która zajmowała się produkcją autobusów. Przeniesienie i rozszerzenie produkcji w Sanoku nie pomogło Autosanowi. Niska jakość, brak innowacyjnych rozwiązań i opóźnienia w realizacji kontraktów przyczyniły się do utraty przez polskiego producenta monopolu na krajowym rynku. Ze względu na coraz mniejszą sprzedaż autobusów międzymiastowych w Polsce oraz spadek eksportu wielkość produkcji została znacząco zmniejszona i w 2010 roku wyniosła zaledwie 112 sztuk. Autosan SA w ostatnich kilku latach generował poważne straty, co doprowadziło do wyczerpania możliwości dalszego finansowania działań restrukturyzacyjnych i działalności gospodarczej spółki.

19 września 2013 roku firma ogłosiła upadłość. Grupa Sobiesław Zasada SA sprzedała wówczas posiadane akcje spółki Autosan (ok. 92\%), które nabył Grzegorz Tarnawa. Sąd Gospodarczy w Krośnie 7 października 2013 roku wydał postanowienie o ogłoszeniu upadłości likwidacyjnej Spółki Akcyjnej Autosan, wyznaczając przy tym sędziego komisarza i syndyka Ludwika Noworolskiego. W rezultacie Grzegorz Tarnawa odsprzedał część zakupionych akcji spółki, które nabyli: Krzysztof Moska (prezes firmy Gamrat) i Leszek Sobik, sobie zaś pozostawił pakiet większościowy. Do czasu ogłoszenia upadłości w fabryce zatrudniano 481 osób. Załoga została grupowo zwolniona z wypowiedzeniem, jednak syndyk zatrudnił ponownie w Autosanie 360 osób, a 120 otrzymało zasiłki przedemerytalne. Syndyk zapowiedział także zwiększenie zatrudnienia oraz przeznaczenie środków na badania i rozwój. Do marca 2013 roku Autosan wyprodukował łącznie 109407 autobusów (Walczak, 2013).

Fabryka Autobusów Solbus sp. z o.o., mająca siedzibę w Solcu Kujawskim w powiecie bydgoskim na Kujawach, powstała w 2001 roku wskutek upadłości działających wcześniej przez 40 lat Kujawskich Zakładów Napraw Samochodowych, największych w Polsce zakładów naprawczych ciężkiego sprzętu transportowego. W 2003 roku większościowy pakiet udziałów w zakładach Solbus przejął Antoni Śliżak, właściciel firmy Blue Line, zajmującej się sprzedażą i leasingiem autobusów. Przedsiębiorstwo prężnie się rozwijało i w 2004 roku zostało wiceliderem na polskim rynku. Solbus był związany umową licencyjną z czeskim 
SOR-em do 2007 roku. Po rozwiązaniu umowy Czesi oskarżyli Solbus o plagiat części autobusów i był to początek problemów dla polskiego przedsiębiorstwa.

Rozpoczęto rozwijanie sieci sprzedaży i serwisu w Wielkiej Brytanii, jednak kryzys gospodarczy zmusił zarząd do wycofania się z tej inwestycji. W 2009 roku nastąpiło załamanie się sprzedaży w segmencie autobusów międzymiastowych - strategicznym segmencie producenta z Solca Kujawskiego. Dodatkowo nowa technologia pochłaniała kolejne nakłady na infrastrukturę. Szansą dla Solbusa miała być dostawa 31 autobusów zasilanych gazem ziemnym (LNG) na obsługę części krakowskich linii. Ostatecznie podczas próby drogowej przeprowadzonej 23 kwietnia 2010 roku spłonął autobus Solbus Solcity napędzany LNG. Pożar powstał wskutek uszkodzenia węża hydraulicznego napędu wentylatora i stał się przysłowiowym gwoździem do trumny przedsiębiorstwa. Sąd Gospodarczy w Bydgoszczy 7 lipca 2010 roku ogłosił upadłość fabryki autobusów Solbus. Firma zawarła 9 marca 2012 roku układ z wierzycielami dający jej 4 lata na spłatę zadłużenia (Kierecki, 2010).

Pozytywnym aspektem w tej trudnej sytuacji rodzimych producentów jest to, że prawo upadłościowe i naprawcze narzuca przedsiębiorstwom w stanie upadłości lub wdrażającym proces naprawczy pewne minimum w zakresie restrukturyzacji, a mianowicie przedstawienie takich propozycji układowych, które zaspokoją roszczenia wierzycieli w jak największym stopniu. Jeśli organizacje chcą przetrwać sytuację kryzysową, muszą opracować plan restrukturyzacji naprawczej - zarówno wymaganej przez prawo restrukturyzacji zobowiązań, majątku, zatrudnienia, jak i podyktowanej racjonalnym zarządzaniem strategii działania. Są to działania stabilizujące, których celem jest przywrócenie przedsiębiorstwu utraconej sprawności. Konieczne jest także dostosowanie się do otoczenia, w którym działa firma (Bauer, 2010).

\section{NAJWIĘKSI PRODUCENCI Autobusów w Polsce}

Na przełomie XX i XXI w. nastąpiły zmiany uwarunkowań prowadzenia działalności gospodarczej w Polsce, które doprowadziły do tego, że tradycyjne formy koncentracji przemysłu straciły wagę. W warunkach globalizacji i internacjonalizacji życia gospodarczego rośnie znaczenie przewagi konkurencyjnej poszczególnych regionów jako potencjalnych miejsc prowadzenia działalności gospodarczej (Gierańczyk, 2008).

Światowe korporacje, poszukując nowych miejsc efektywnej lokalizacji, często w znacznym stopniu dyktują warunki funkcjonowania swoich firm na terenie poszczególnych krajów i regionów. Dlatego to nie korporacje, ale różnej skali układy przestrzenne, poprzez podnoszenie swojej atrakcyjności dla nowych inwestycji, starają się stworzyć jak najkorzystniejsze warunki, aby przyciągnąć inwestorów, a wraz z nimi nowe formy działalności gospodarczej, zmierzają również do pobudzania wewnętrznych czynników rozwojowych (Zioło, 2009).

W początkowym okresie procesu kształtowania się międzynarodowych korporacji lokalizacja nowego zakładu produkcyjnego związana była z krajem pochodzenia konstruktora. 
Później przedsiębiorstwa lokowały nowe zakłady w krajach, które dysponowały dużym rynkiem zbytu dla wytwarzanych przez nie produktów. Istotnym czynnikiem dla nowej lokalizacji było również ograniczenie kosztów transportu. Dzisiaj wybór najkorzystniejszego położenia dla inwestycji stanowi złożony proces i jest integralnym elementem strategii globalizacyjnej każdego przedsiębiorstwa. Na podjęcie decyzji o przeniesieniu produkcji lub rozpoczęciu jej w nowym miejscu ma wpływ wiele aspektów, do których zalicza się m.in.: czynniki związane z optymalizacją procesu produkcji, z poszukiwaniem i dopasowywaniem się do nich oraz czynniki polityczne (Merkisz-Guranowska, Merkisz, 2007).

W Polsce znajduje się kilka zakładów branży autobusowej należących do międzynarodowych koncernów motoryzacyjnych. Inwestują one w państwach Europy Środkowej, kierując się w głównej mierze dostępem do zasobów wytwórczych tych krajów oraz dużym rynkiem zbytu. Koncerny te, podejmując strategiczne decyzje inwestowania, wybierają region, który jest zgodny z celami inwestycyjnymi korporacji. Kolejnym krokiem jest negocjowanie określonych warunków inwestowania z władzami danego państwa. W Europie Środkowej jako atrakcyjne lokalizacje inwestycji nadal rozważa się cztery kraje: Czechy, Polskę, Słowację i Węgry (Lizak, 2011).

Zdecydowanym liderem wśród producentów autobusów w Polsce jest MAN Bus sp. z o.o. Spółka należy do niemieckiego koncernu MAN SE i specjalizuje się w produkcji autobusów miejskich. Zakład w województwie świętokrzyskim mieści się w byłych halach Fabryki Samochodów Ciężarowych Star i podlega pod Specjalną Strefę Ekonomiczną Starachowice SA. Wytwarzanie szkieletów niskopodłogowych w Starachowicach rozpoczęto w 2004 roku, wówczas firma nazywała się MAN Star Trucks \& Buses Sp. z o.o. Obecnie MAN Bus Sp. z o.o. w Polsce posiada dwa zakłady produkcyjne: zakład produkujący szkielety stalowe autobusów, podwozia autobusowe i podzespoły do nich w Starachowicach oraz zakład w Sadach, w gminie Tarnowo Podgórne koło Poznania, gdzie odbywa się końcowy proces produkcji (Ćwikła, 2013).

Solaris Bus \& Coach SA jest największym polskim producentem autobusów miejskich, międzymiastowych i specjalnych. Solaris to przedsiębiorstwo rodzinne, którego założycielami i właścicielami są Solange i Krzysztof Olszewscy. Jest to doskonały przykład na to, że jednym z głównych czynników decydujących o powodzeniu procesu restrukturyzacji w przemyśle jest czynnik ludzki. To ludzie zatrudnieni w przedsiębiorstwie są realizatorami wszelkich zmian, stąd tak duże znaczenie mają ich dążenia, postawy i cechy: wykształcenie, zdolności przewidywania, umiejętności organizatorskie, przedsiębiorczość, kreatywność, zdolność wchłaniania innowacji. Według badań najczęstszymi inicjatorami zmian są członkowie kadry zarządzającej oraz rad pracowniczych przedsiębiorstw (Rachwał, 2008). W 1996 roku produkcja autobusów marki Solaris została uruchomiona w fabryce w Bolechowie pod Poznaniem. Firma liczy się na europejskim rynku, wyprodukowano już ponad 11 tys. pojazdów, które jeżdżą po drogach 28 krajów (www.solarisbus.com).

Działalność koncernu Scania AB w Polsce rozpoczęła się w 1992 roku, kiedy to został otwarty zakład produkcyjny w Słupsku. Duży wpływ miało na to funkcjonowanie w mieście Komunalnego Przedsiębiorstwa Naprawy Autobusów Kapena. Utworzona została wówczas spółka joint venture Scania-Kapena SA, która wykorzystała dotychczasowy profil 
działalności i związany z nim park maszynowy oraz doświadczenie i umiejętności przy relatywnie niskich kosztach pracy polskiego udziałowca. Istotna była również dostępność komunikacyjna Słupska i korzystne położenie geograficzne względem Szwecji oraz potencjalnych rynków Europy Środkowo-Wschodniej. W 1994 roku rozpoczęto produkcję autobusów Scania CN113CLL, początkowo na poziomie 20-30 pojazdów rocznie. Eksport podwozi autobusowych do innych zakładów koncernu Scania i odbiorców zewnętrznych rozpoczął się rok później. Zakłady Scania w Słupsku od lipca 2002 roku produkują wyłącznie autobusy miejskie i podwozia autobusów typu N. Obecna nazwa zakładu to Scania Production Słupsk SA (Czapliński, Stawarska, 2010).

Volvo Polska Autobusy jest częścią koncernu Volvo Bus Corporation, jednego z największych producentów autobusów na świecie. Firma sprzedaje autobusy miejskie, międzymiastowe i turystyczne, produkowane w fabryce Volvo we Wrocławiu. Zakład ten jest obecnie największą i najnowocześniejszą fabryką autobusów Volvo w Europie. Produkcja obejmuje zintegrowane procesy montażu podwozia i nadwozia. Pojazdy są dostarczane na rynki całej Europy, a ich odbiorcami są przedsiębiorstwa komunikacji miejskiej, przewoźnicy na trasach międzymiastowych i międzynarodowych oraz biura turystyczne (www.volvobuses.com).

\section{Produkcja autobusów w Polsce w latach 2010-2013}

Proces dostosowania się przedsiębiorstw przemysłowych do nowych warunków gospodarowania wymaga od nich przeprowadzenia głębokich zmian w funkcjonowaniu, prowadzących do podniesienia ich konkurencyjności. Zmiany te warunkują uczestnictwo krajowych firm przemysłowych w globalnych procesach gospodarczych i integrację polskiego przemysłu z przemysłem światowym, zwłaszcza w drodze powiązań organizacyjnych, kapitałowych, technologicznych i wchodzenia w ukształtowane sieci rynkowe ponadnarodowych korporacji. Dlatego też z punktu widzenia analizy procesu transformacji gospodarczej w Polsce, w szczególności transformacji struktur przemysłowych, istotna wydaje się problematyka badawcza funkcjonowania poszczególnych przedsiębiorstw przemysłowych (Rachwał, 2008).

W Polsce funkcjonują fabryki takich zagranicznych firm, jak: MAN Bus, Scania Production Słupsk czy Volvo Buses. Należy pamiętać również o rodzimym producencie pojazdów komunikacji miejskiej - Solaris Bus \& Coach. Wielkość produkcji autobusów w Polsce została szczegółowo przedstawiona na ryc. 6. Największym ich producentem jest firma MAN Bus. Spółka produkuje również kompletne podwozia, których w 2010 roku wyeksportowano ponad 600 sztuk. Ich główni odbiorcy to producenci zabudów w Izraelu, Hiszpanii i Niemczech, ale są wśród nich również odbiorcy z takich egzotycznych krajów, jak Malezja, Hongkong czy Chiny.

Wicelider w produkcji autobusów - Solaris - realizował w 2010 roku kontrakty na dostawę gazowych autobusów niskopodłogowych do Szwecji, Niemiec i Francji. W Bolechowie 
uruchomiono produkcję autobusów hybrydowych Urbino 12 Hybrid oraz szeregową hybrydę Voisloh Kieppe na bazie Urbino 18.

Przedsiębiorstwo Volvo Polska w 2010 roku wyprodukowało 855 autobusów, w tym 60 autobusów hybrydowych Volvo 7705 Hybrid. Na eksportowej liście Volvo pojawiły się nowe kraje, wzrósł również eksport na ogromy francuski rynek.

Scania Production Słupsk 14 września 2010 roku uruchomiła nową linię produkcyjną, która miała wpływać na zwiększoną efektywność zakładu. Scania w Słupsku posiada bardzo mocno zdywersyfikowaną ofertę produkcyjną. Powstają tam zarówno autobusy zasilane etanolem (również wersje przegubowe i trzyosiowe), jak i piętrowe pojazdy przeznaczone na rynek brytyjski. Scania realizowała liczne kontrakty na dostawę pojazdów zasilanych CNG.

Stosunkowo dobry wynik, z liczbą 159 autobusów w 2010 roku, zanotowała firma CMS Auto, która specjalizuje się w produkcji autobusów, minibusów oraz pojazdów specjalistycznych w oparciu o samochody bazowe. Na kolejnych miejscach uplasowały się następujące marki: Autosan - 112 pojazdów, Kapena - 83 i Solbus - 12 autobusów (Kierecki, 2010).

W 2011 roku produkcja autobusów w Polsce osiągnęła poziom 4632 sztuk. Wzrost o $11,13 \%$ w porównaniu do roku poprzedniego był spowodowany większą sprzedażą autobusów w kraju oraz rosnącym eksportem. Liderem wśród producentów autobusów w Polsce w dalszym ciągu był MAN Bus, który w 2011 roku wyprodukował 1566 autobusów, czyli aż o 299 pojazdów $(+23,59 \%)$ więcej niż rok wcześniej, oraz 650 podwozi. W tym samym roku MAN Bus zmodernizował swoją linię produkcyjną, wdrażając projekt 888 , czyli montaż w ciągu jednej zmiany 8 jednostek w 8 godzin przy 80 autobusach znajdujących się w toku produkcyjnym. Ważnym elementem rozwoju produkcji MAN w Polsce było uruchomienie w sierpniu 2011 roku seryjnej produkcji szkieletów autokarów Neoplan Cityliner i Starliner. Produkowane w Starachowicach korpusy, zabezpieczane przez kataforetyczne malowanie zanurzeniowe, eksportowane są do niemieckiej fabryki MAN w Plauen.

Drugie miejsce wśród producentów autobusów w Polsce zajął Solaris Bus \& Coach. Bramy fabryki w Bolechowie opuściło łącznie 1140 autobusów (wzrost o 11,54\%). Pojazdy wyprodukowane w 2011 roku trafiły w głównej mierze do klientów polskich (m.in. Warszawa i Białystok) oraz niemieckich (m.in. Frankfurt, Fulda i Bochum), duńskich (m.in. Kopenhaga i Aarhus) i norweskich (Unibus Oslo). Solaris sprzedał również swoje autobusy do Serbii i Rumunii (Oradea). Producent prowadził w 2011 roku prace nad pierwszym polskim autobusem elektrycznym, który miał swoją premierę na wrześniowych targach w Kielcach.

Volvo Buses utrzymało swoją trzecią pozycję z zeszłego roku, wyprodukowawszy w 2011 roku łącznie 922 autobusy (wzrost o 7,83\%). Firma wprowadziła na rynek autobus nowej generacji Volvo 8900. Jego konstrukcja w znacznej mierze jest oparta na aluminium i tworzywach sztucznych, co wymagało reorganizacji całej linii produkcyjnej.

W 2011 roku Scania Production Słupsk wyprodukowała 500 pojazdów $(-24,01 \%)$ mniej niż przed rokiem, ale jednak utrzymała swoją pozycję na rynku. Zmniejszona produkcja związana była z brakiem większych zamówień na piętrowe autobusy miejskie z Wielkiej Brytanii, które do tej pory były jednym z filarów produkcji zakładu. Firma zrealizowała liczne kontrakty na dostawę pojazdów zasilanych CNG (sprężonym gazem ziemnym). 
Różnice pomiędzy pierwszą czwórką a pozostałymi producentami w Polsce są bardzo duże. Na piątej pozycji znajduje się Kapena - 172 wyprodukowane autobusy, za nim uplasowały się Autosan, CMS, Solbus i AMZ (Raport 2012, PZPM).

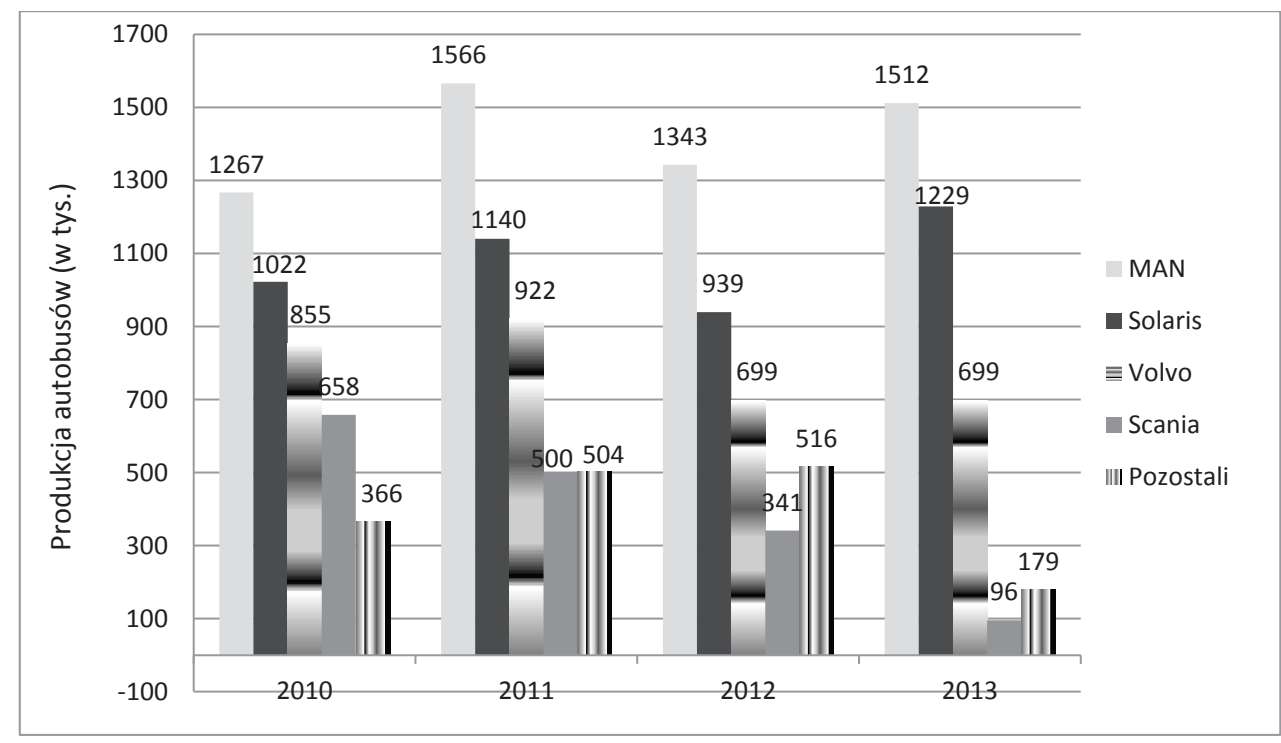

Ryc. 6. Produkcja autobusów w Polsce w latach 2010-2013

Źródło: opracowanie własne na podstawie JMK Analizy Rynku Transportowego

Produkcja autobusów w Polsce w 2012 roku osiągnęła poziom 3838 sztuk. Jest to o 938 pojazdów mniej niż w 2011 roku (-19,63\%). Spadek ten został spowodowany mniejszym eksportem autobusów oraz malejącym popytem na krajowym rynku. Liderem pozostał MAN Bus, który w 2012 roku wyprodukował 1343 autobusy, czyli o 224 (-14,24\%) mniej niż w 2011 roku. Do tego wyniku trzeba dopisać ponad 500 podwozi (wysłanych m.in. do Singapuru, Hiszpanii, Izraela) oraz prawie 300 szkieletów konstrukcyjnych autobusów turystycznych marki Neoplan. Drugie miejsce w rankingu w 2012 roku zajął Solaris Bus \& Coach. Bramy polskiej fabryki w Bolechowie opuściło łącznie 939 autobusów (mniej o 17,63\% w stosunku do roku poprzedniego). Trzecie miejsce zajęło Volvo, które w 2012 roku wyprodukowało łącznie 699 autobusów (o 34,62\% mniej niż w 2011 roku). Czwarte miejsce w rankingu należy do Scania Production Słupsk. W 2012 roku szwedzka firma zmontowała 341 autobusów, czyli o 47,04\% mniej niż w 2011 roku (Raport 2013, PZPM).

W 2013 roku produkcja autobusów w Polsce osiągnęła poziom 3715 szt. (4,17\% więcej niż w 2012 roku). Po bardzo słabym pierwszym półroczu produkcja w końcu roku nabrała tempa, a zasługą tego jest duży eksport, który jeszcze w pierwszym kwartale był na minusie. Do tego wzrostu przyczyniła się również zmiana przepisów dotyczących norm spalania. Od 2014 roku wszystkie nowo rejestrowane pojazdy muszą spełniać wymagania normy czystości spalin Euro 6. Spowodowało to w konsekwencji wzrost cen autobusów nowszej technologii, 
może też doprowadzić do większej awaryjności nowych pojazdów. Zamawiający, chcąc uniknąć dodatkowych kosztów, przesunęli terminy realizacji z 2014 na koniec 2013 roku.

W 2011 roku aż 958 wyprodukowanych w Polsce autobusów trafiło do rodzimych przewoźników (udział 20,68\%). Oznacza to, że co piąty autobus, który w tym roku opuścił bramy fabryk zlokalizowanych w naszym kraju trafił następnie na nasze drogi czy ulice. W tym roku odnotowano też wzrost sprzedaży nowych autobusów w Polsce o 28\%. Łącznie krajowi przewoźnicy zakupili 1377 autobusów, o 305 więcej niż rok wcześniej.

W 2012 roku zarejestrowano w naszym kraju 1279 autobusów, czyli o 282 mniej niż przed rokiem $(-18,06 \%)$. Rejestracja nowych autobusów w Polsce pokazuje, że na polskim rynku autobusowym liderem jest Mercedes-Benz. W 2013 roku firma sprzedała na polski rynek aż 542 pojazdy. Drugie miejsce w rankingu z wysokim wynikiem zajął Solaris Bus \& Coach - 318 autobusów. Na trzecim miejscu, z liczbą 63 pojazdów, uplasował się MAN Bus. Czwarte miejsce zajął Autosan - zarejestrowano 62 nowe pojazdy tej marki w Polsce. Następne pozycje zajęły odpowiednio marki Solbus i Iveco (Kierecki, 2014b). Dane dotyczące poprzednich lat zostały przedstawione w tab. 3 .

Tab. 3. Rejestracje nowych autobusów w Polsce w latach 2010-2013

\begin{tabular}{|l|c|c|c|c|c|c|c|c|}
\hline \multirow{2}{*}{ Marka } & \multicolumn{2}{|c|}{2010} & \multicolumn{2}{c|}{2011} & \multicolumn{2}{c|}{2012} & \multicolumn{2}{c|}{2013} \\
\cline { 2 - 10 } & $\begin{array}{c}\text { Ogółem } \\
\text { (szt.) }\end{array}$ & Udział (\%) & $\begin{array}{c}\text { Ogółem } \\
\text { (szt.) }\end{array}$ & Udział (\%) & $\begin{array}{c}\text { Ogółem } \\
\text { (szt.) }\end{array}$ & $\begin{array}{c}\text { Udział } \\
\text { (\%) }\end{array}$ & $\begin{array}{c}\text { Ogółem } \\
\text { (szt.) }\end{array}$ & $\begin{array}{c}\text { Udział } \\
(\%)\end{array}$ \\
\hline $\begin{array}{l}\text { Mercedes- } \\
\text {-Benz }\end{array}$ & 421 & 30,73 & 438 & 28,06 & 453 & 35,42 & 542 & 39,02 \\
\hline Solaris & 395 & 28,83 & 487 & 31,2 & 257 & 20,09 & 318 & 22,89 \\
\hline Autosan & 108 & 7,88 & 153 & 9,8 & 83 & 6,49 & 62 & 4,46 \\
\hline MAN & 103 & 7,52 & 86 & 5,51 & 70 & 5,47 & 63 & 4,54 \\
\hline Scania & 39 & 2,85 & 65 & 4,16 & - & - & 35 & 2,52 \\
\hline Iveco-Irisbus & 38 & 2,77 & 83 & 5,32 & 59 & 4,61 & 48 & 3,46 \\
\hline Setra & 22 & 1,61 & 31 & 1,99 & 56 & 4,38 & 42 & 3,02 \\
\hline Solbus & 11 & 0,8 & 45 & 2,88 & 60 & 4,69 & 52 & 3,74 \\
\hline Pozostali & 233 & 17,01 & 173 & 11,08 & 241 & 18,84 & 227 & 16,35 \\
\hline Ogółem & 1370 & 100 & 1561 & 100 & 1279 & 100 & 1389 & 100 \\
\hline
\end{tabular}

Źródło: opracowanie własne na podstawie danych PZPM i JMK

\section{Podsumowanie}

Produkcja autobusów odgrywa istotną rolę w sektorze motoryzacyjnym naszego kraju. Do firm produkujących autobusy możemy jeszcze zaliczyć takie, które zarządzają typowo polskim kapitałem. Należy do nich wyrastający na jednego ze znaczących w Europie producentów autobusów - Solaris Bus \& Coach. Niestety, pozostałe polskie przedsiębiorstwa (Autosan, Solbus) obecnie funkcjonują w oparciu o prawo upadłościowe. 
Polska staje się europejskim centrum produkcji autobusów miejskich. W naszym kraju ich produkcja jest rozproszona, a fabryki znajdują się w kilku województwach. W ostatnich latach utrzymuje się ona na ustabilizowanym poziomie (4-4,5 tys. pojazdów), co jest uwarunkowane eksportem autobusów oraz popytem na krajowym rynku (dofinansowanie z funduszy UE). Największymi producentami autobusów w Polsce od kilku lat są niezmiennie: MAN Bus, Solaris Bus \& Coach, Volvo Buses i Scania Production Słupsk. Bezkonkurencyjnym liderem sprzedaży w naszym kraju pozostaje firma Mercedes-Benz.

\section{Literatura \\ References}

Bauer. K. (2010). Kryzys finansowy a restrukturyzacja przedsiębiorstw w stanie upadłości. Prace Komisji Geografii Przemystu Polskiego Towarzystwa Geograficznego, 15, 209-218.

Chłopek, Z., Radzimirski, S., Taubert, S., Waśkiewicz, J. (2011). Opracowanie metodologii prognozowania zmian aktywności sektora transportu drogowego. Warszawa: Zakład Badań Ekonomicznych Instytutu Transportu Samochodowego, 22-156.

Czapliński, P., Stawarska, A. (2010), Przejawy procesu globalizacji w sferze produkcji na przykładzie Scania Production Słupsk SA. Prace Komisji Geografii Przemystu Polskiego Towarzystwa Geograficznego, 16, 176-186.

Ćwikła, M. (2013). Fabryka Samochodów Ciężarowych Star - narodziny i zmierzch polskiego „giganta" przemysłu motoryzacyjnego. W: G. Chybicki (red.). Wspótczesne problemy rozwoju gospodarczego. Płock: Wydawnictwo Politechniki Warszawskiej, Kolegium Nauk Ekonomicznych i Społecznych w Płocku, 146-160.

Gierańczyk, W. (2008). Badanie struktur przemysłowych w Polsce w dobie globalizacji ze szczególnym uwzględnieniem struktury przestrzennej. Prace Komisji Geografii Przemystu Polskiego Towarzystwa Geograficznego, 10, 27-39.

Lizak, P. (2011). Proces kształtowania się słowackiego przemysłu motoryzacyjnego jako wyraz konkurencyjności regionu. Prace Komisji Geografii Przemystu Polskiego Towarzystwa Geograficznego, $17,144-154$.

Kierecki, A. (2010) (2014, 17 stycznia). Solbus ogłasza upadłość. Pozyskano z www.infobus.p1/text. php?id=33932

Kierecki, A. (2013) (2014, 3 lutego). Produkcja autobusów w ciagu III kwartałów 2013 roku. Pozyskano z www.infobus.pl/text.php?id=61792

Krzemiński, J. (2013, 12 listopada). Komunikacja miejska ciągnie w dół finanse samorządów. Obserwator Finansowy. Pozyskano z www.obserwatorfinansowy.pl/forma/ analizy/komunikacja-miejska-ciagnie-w-dol-finanse-samorzadow

MAN, Polska (2013, 15 listopada). Pozyskano z www.mantruckandbus.pl

Merkisz-Guranowska, A., Merkisz, J. (2007). Wybrane aspekty globalizacji w przemyśle motoryzacyjnym. W: M. Kupczyk (red.). Najnowsze osiągnięcia i kierunki rozwoju technologii maszyn. Zeszyty Naukowe Politechniki Poznańskiej - Budowa Maszyn i Zarządzanie Produkcją. Poznań: Wydawnictwo Politechniki Poznańskiej, 99-100.

Osenkowski, Z. (1995). Od kotłów po pojazdy szynowe Fabryki Sanockiej. Roczniki Sanockie. Sanok: Towarzystwo Rozwoju i Upiększania Miasta Sanoka, 94-95.

Polska 2012. Raport o stanie handlu zagranicznego (2012, 13 listopada). Ministerstwo Gospodarki. Pozyskano z www.mg.gov.pl/files/upload/8437/PL_MG_DSA_MWP_Polska_2012_Raport_o_ stanie_hz_w_ost.pdf 
Polski Związek Przemystu Motoryzacyjnego (2013, 14 listopada). Pozyskano z: www.pzpm.org.pl/ Europa

Rachwał, T. (2008). Problematyka badawcza funkcjonowania przedsiębiorstw przemysłowych. Prace Komisji Geografii Przemystu Polskiego Towarzystwa Geograficznego, 10, 46-52.

Raport 2012. Branża motoryzacyjna. Rocznik Polskiego Związu Przemystu Motoryzacyjnego, 39-44. Raport 2013. Branża motoryzacyjna. Rocznik Polskiego Związku Przemyslu Motoryzacyjnego, 48-53. Scania Production Słupsk S.A. (2013, 16 listopada). Pozyskano z www.scaniaproductionslupsk.pl Solaris Bus \& Coach S.A. (2013, 15 listopada). Pozyskano z www.solarisbus.com Volvo Polska Autobusy (2013, 15 listopada). Pozyskano z volvobuses.com

Walczak, M. (2013, 11 grudnia). Autosan ogłasza upadłość. Co dalej z autobusową legendą? Newsweek Polska. Pozyskano z biznes.newsweek.pl/upadlosc-autosana-co-dalej-z-autobusami-z-sanokanewsweek-pl,artykuly,270734,1.html

Wieloński, A. (2010). Wielkość i struktura eksportu miarą konkurencyjności polskiego przemysłu. Prace Komisji Geografii Przemystu Polskiego Towarzystwa Geograficznego, 15, 99-104.

Załącznik 1 do Strategii Rozwoju Transportu. (2013, 2 listopada). Diagnoza polskiego transportu. Ministerstwo Infrastruktury. Pozyskano z www.transport.gov.pl/files /0/1793988/ Za01SRTDiagnozatransportu Polski280311.pdf

Zioło, Z. (2009). Procesy kształtowania się światowych korporacji i ich wpływ na otoczenie. Prace Komisji Geografii Przemystu Polskiego Towarzystwa Geograficznego, 12, 11-32.

Zioło, Z. (2010), Uwarunkowania kształtowania się procesów transformacji przemysłu i usług. Prace Komisji Geografii Przemystu Polskiego Towarzystwa Geograficznego, 15, 45-60.

Mateusz Ćwikła, ukończył inżynierię środowiska na Politechnice Świętokrzyskiej i studia magisterskie z geografii (specjalizacja gospodarka przestrzenna) na Uniwersytecie Jana Kochanowskiego w Kielcach. Jest stypendystą MNiSW, Fundacji Sapere Auso oraz Fundacji Wiatr w Żagle. Laureat ogólnopolski branży przyrodniczo-rolniczej w Konkursie na Najlepszego Studenta RP Studencki Nobel 2012, uzyskał również tytuł Najlepszego Studenta RP „Primus Inter Pares” 2012. Opublikował 18 artykułów naukowych z zakresu kształtowania środowiska, hydrogeologii, antropogeografii oraz geografii społeczno-ekonomicznej. Jest również autorem książki Jankowa na przestrzeni dziejów. Interesuje się przemysłem oraz ekologią. Pracuje w firmie MAN Bus sp. z o.o., oddział w Starachowicach. Obecnie jest doktorantem Instytutu Geografii Uniwersytetu Pedagogicznego w Krakowie.

Mateusz Ćwikla, studied Environmental Engineering at Kielce University of Technology and Geography at The Jan Kochanowski University in Kielce. He is a scholar of Ministry of Science and Higher Education, as well as "Sapere Auso" and "Wiatr w Żagle" foundations. He is a laureate of the national competition "Studencki Nobel 2012" and he was granted the title of the Best Student of the Republic of Poland "Primus Inter Pares" in 2012. He has published 18 scientific articles on environmental management and planning, hydrogeology, and human geography, including economic and social geography. He is the author of the book Jankowa na przestrzeni dziejów. His interests include industry and ecology. He is employed in MAN Bus Ltd. He is a doctoral student at the Insitute of Geography at Pedagogical University of Cracow.

\section{Adres/address:}

Uniwersytet Pedagogiczny w Krakowie

Instytut Geografii

ul. Podchorążych 2, 30-084 Kraków, Polska

e-mail: mat.cwikla@gmail.com 